\title{
MONSTRØSITET SOM KULTUREL OG RELIGIØS DISKURS
}

- illustreret af monstertraditioner fra det gamle Mesopotamien ${ }^{1}$

\author{
Laura Feldt
}

\section{Indledning}

Nutidens kultur vrimler med monstre: fra Pokémon til Frankenstein, fra film som Species og Interview with the Vampire til støttegrupper for folk, der har været bortført af aliens, florerer monsterkulturen. Men interessen for monstrene er ikke særlig for vores tid. Religionshistorien er fuld af dem. Allerede fra de gamle mesopotamiske kulturer, der var indflydelsesrige i Nærorienten i perioden fra ca. 3000 f.v.t. til ca. 500 f.v.t., kender vi mange traditioner om monstre i både litteratur og kunst. Monstrøsitet som fænomen er således både aktuelt og af tilsyneladende almenmenneskelig karakter. Denne artikel er tænkt som et forsøg på at forstå og fortolke dens betydning. ${ }^{2}$

Artiklen har to perspektiver. Det første omhandler monstrøsitet som kulturel diskurs. Monstrets kulturelle betydning har været genstand for antropologiske undersøgelser, og med afsæt heri fremlægger jeg en antropologisk læsning af monstrøsitet, der forstår den som grænsefænomen og fortolker dens sociale funktion i forlængelse af René Girard. At en sådan læsning dog ikke er helt dækkende i forhold til brug af monstre i religiøse diskurser, viser artiklens andet perspektiv, der undersøger monstrøsitet som religiøs diskurs. Her udfoldes en læsning af monstrøsitet, som i forlængelse af Victor Turner relaterer den til liminalitet. Liminalitetsforståelsen udfoldes i relation til fænomenet 'portal' og forstås dermed som ikke alene relateret til ritualer, men også som en spatial og konceptuel størrelse. Det hævdes, at monstre kropsliggør adgang til transcendensens transformerende kræfter, ${ }^{3}$ og således kan anvendes både til at hidkalde godt og bortsende ondt. Monstre er stigmatiserede pendlere mellem 'denne verden' og det 'hinsi-

\footnotetext{
${ }^{1}$ En tak rettes til redaktionen af $R v T$, særligt A. Klostergaard Petersen, for værdifulde kommentarer og konstruktiv kritik i forbindelse med udarbejdelsen af denne artikel.

${ }^{2}$ Ifølge Sextus Pompeius Festus, en grammatiker fra det andet århundrede, som opsummerede Marcus Verrius Flaccus' De verborum significatu, afledes ordet monstrum af monestrum af roden moneo. Dette verbums grundbetydning (af roden memini, mens) er at 'minde nogen om noget', 'at få nogen til at huske', 'at advare', 'informere', 'opfordre'. Monstro betyder 'at vise', 'indikere', 'foreskrive', 'rådgive' (Marin 1993, 400).

3 Termen 'transcendens' bruges her til at angive strukturelle principper eller relationer i et niveau, der ligger uden for det niveau af strukturer og relationer, som tages som referencepunkt, den 'normale', hverdagslige verden af social orden på et givet tidspunkt. Transcendens er således defineret ved afvigelse eller brud og bærer ikke nødvendigvis hellighedskonnotationer. Det samme intenderes ved anvendelsen af termerne 'hinsides' og 'her' som spatielle markører på en given italesættelse af hierarkisk organisering af verden og konceptualiseringen af en 'anden' (overnaturlig, transempirisk) verden.
} 
des'. Dette illustreres i artiklens sidste del ved hjælp af de mesopotamiske monstertraditioner.

\section{Vi og de andre: monstrøsitet som kulturel diskurs}

Hvad er det, der tillader placeringen af drager, varulve, King Kong, aliens og Minotauros i samme kategori? Hvad er egentlig et monster? Noget af det, monstre har til fælles, er en afvigelse fra en norm om fysisk integritet. Monstret er 'kropsligt ekstrem'; det er en skikkelse, i hvilken de kategoriale grænser mellem det menneskelige, det animalske og det stofligt/tingslige bryder sammen. ${ }^{4}$ Normen om en fysisk entydig menneskelig identitet er forskelligt bestemt fra kultur til kultur, men en virtuel model for kropsforestillingen ligger altid til grund, ifølge hvilken kroppens funktioner og proportioner passer sammen, harmonerer. På den ene side bestemmes den enkeltes identitet ud fra graden af afvigelse fra modelkroppen, men hvis grænsen til de andre kategorier af ontologisk organisation på den anden side overskrides, så begribes denne afvigelse, overskridelse som anderledes, som monstrøs (Brittnacher 1994, 183-7). I det monstrøse fremstilles eller trækkes grænsen mellem menneskeligt og ikke-menneskeligt. Det truer kategorierne, f.eks. kategorien 'menneske', fordi det på den ene side kropsliggør alt det, der kan opløse mennesket som menneske. På den anden side er det individuelle menneske bestemt netop ved sin afvigelse fra ideal/modelkroppen (kategoriseringens 'menneske'). Monstrøse kroppe er hybrider, sammensatte kroppe, der netop er bestemt ved at tilhøre mere end en kategori. I kraft af deres grænseoverskridende form tematiseres dermed kategoriseringen qua kategorisering.

I litteraturteorien er der opstået en interesse for, hvordan man kan forklare og forstå monstrøsitet. Som repræsentativt eksempel har jeg valgt J.J. Cohen, der i 1996 udgav bogen Monster Theory - Reading Culture - en antologi viet til antropologisk monsterfortolkning af litteraturens monstre. Cohen ser monstrenes kroppe som kulturelle konstruktioner, der tematiserer en given kulturs kategoriseringer. Netop fordi den kulturelle og religiøse kategori 'monster' repræsenterer det vanskeligt kategoriserbare, får monstre rollen som de forstyrrende hybrider - væsener, som ikke kan inkluderes i en systematisk klassifikation. De virker forstyrrende på orden og struktur, fordi de overtræder grænser og normer ved at rumme forskellige kategorier. Af den grund opfattes de som farlige væsener, der ikke lader sig kontrollere eller entydigt afkode. De dukker op i krisetider og bebor verdens margener, begrebsligt, ikke geografisk, forstået; dvs. udkanten af kulturen, grænselandet, og dermed klassifikationens system (Cohen 1996, 3-6, jf. også

\footnotetext{
${ }^{4}$ Her tænker jeg på muligheden af hybrider af mennesker og ting: f.eks. et tog med menneskeansigt (som det f.eks. kendes fra børnebogsverdenen), biler med individualitet og intentionalitet (Herbie-filmene), talende træer og bjerge, for slet ikke at tale om reklameverdenens blends, talende værktøj, talende rækværk, talende og dansende oste, solbær, appelsiner etc. Religionshistorisk synes dyr/menneske-hybrider dog at være langt hyppigere end andre typer af monstrøsitet. En undersøgelse af, om og hvorfor visse typer af monstrøsitet er mere overlevelsesdygtige, det vil sige bedre egnet til transmission, end andre kunne med fordel foretages i forlængelse af Boyer. Jeg tænker her på ideen om brud eller overskridelse af intuitive ontologiske kategorier, som f.eks. er udfoldet hos Boyer 1994 og 2001, 66-90, 121ff, 132 et passim).
} 
Schade 1962, 37). ${ }^{5}$ Betoningen i mange monsteranalyser ligger på monstret som et negativt, farligt væsen. Cohen hævder videre, at den kulturelle fascination af monstre affødes af ønsket om at navngive det, der er svært at forstå, og af at domesticere det truende. Mange af antologiens bidragydere forbinder netop monstrøsitet med en særlig angsttilstand i samfundet, og lægger særlig vægt på monstret som 'Anden', som noget anderledes og skræmmende (Cohen, 1996, viii, xii et passim i introduktionen, se endvidere Cohen 1996, Waterhouse 1996, Uebel 1996). I common sense opfattelser af monstret i dag ses det også som den Anden, det anderledes - det som står i kontrast til den menneskelige selvforståelse, i hvilken monstrene klassificeres som fremmede. Det aspekt, der ses som relevant i forhold til monstre, er den følelsesmæssige effekt, de har på mennesker: frygt. Den udelukkende negative opfattelse af monstret er imidlertid et moderne fænomen og ifølge Brittnacher betinget af en bestemt historisk udvikling. Han forklarer den som et resultat af kristendommens naturfjendtlige og etiske orientering samt et moderne subjektbegreb, ifølge hvilket mennesket defineres i forhold til dets afstand fra dyrene (Brittnacher 1994, 184; se også Curran et al. 1997). Netop den fremherskende forståelse af monstret som et farligt og skræmmende væsen ønsker jeg at nuancere gennem en udfoldelse af monsterfigurens brug i religiøse diskurser. Der er imidlertid grund til først at diskutere anvendelsen af 'monstre' i kulturelle diskurser.

Monstret som fænomen hører hjemme ved grænserne af den kulturelle diskurs' kategoriseringer. Det står på den ene side uden for disse, men det er på den anden side som grænsefænomen med til at tegne omridset af de sociale rum og kulturelle identiteter. For at indkredse sammenhængen mellem monstrøsitet og grænser og grænseoverskridelse, er det nødvendigt at overveje, hvad en grænse er. Michel de Certeau har i sin analyse af grænselinjer påpeget, at grænser skabes af kontakter: differentieringspunkterne er også de fælles punkter. Grænser er berøringslinjer, og de udgør som sådan en gråzone, der symboliserer udveksling, møde og oversættelse (de Certeau 1984, 127; Uebel 1996, 264f). Grænser opfattes således mere som rum end som linjer. Hvis grænser forstås således, skal monstret ikke udelukkende behandles som 'den(/t) Anden(/t)', det vil sige det fremmede, anderledes og udenfor, men netop som grænsefænomen: et fænomen, der konstant er med til at skabe og udslette grænserne, der skiller inde fra ude, historie fra fiktion, mening fra nonsens. Monstre bebor de huller, der er mellem zoner af erkendelsesmæssig og social betydning, og afslører således de klassifikatoriske grænser som skrøbelige ved altid at true med at opløse grænsen mellem 'anden' og 'samme'.

\footnotetext{
${ }^{5}$ Schade hævder, at det er forståeligt, at randzonerne udgør dæmonernes hjemsted. Ved grænsen for det menneskelige, ved horisonten, får det ukendte og fremmede plads. Grænsen er farens og angstens sted, hvor krige opstår, jf. Brittnacher 1994, 189.

${ }^{6}$ Afsløringstesen er egentlig paradoksal. Monstrene skal hindre 'afsløringer' i at blive alt for tydelige. Overskridelserne skal lukkes inde, afvises. Således er monstrene domesticerende snarere end afslørende. Men eftersom de domesticerer noget afslørende, bevarer de rester af dette. Franco Moretti siger det således: "The monster, then, serves to displace the antagonisms and horrors evidenced within society outside society itself ... The monster, the utterly unknown, serves to reconstruct a universality, a social cohesion which - in itselfwould no longer carry conviction.... The fear aroused by the monster, in other words, is the fear of one who is
} 
Som eksempel kan man tænke på den monstrøse alien i filmtrilogien af samme navn: lige meget hvor mange gange Sigourney Weavers Ripley nedkæmper den udefinerbare alien, der følger hende, dukker den op igen, klar til at terrorisere hende på nye måder. Den sidste film afslører og udtaler eksplicit den snævre sammenhæng mellem monstrøsitet og menneskers grænsedragninger, kategoriseringer og identitetskonstruktioner, idet helten Ripley selv viser sig at være det ultimative monster. Tænk i øvrigt på helterollens karakteristiske tvetydighed. Helten formår, hvad ingen andre i samfundet kan præstere, men står samtidig på grænsen af sin egen gruppe, hvilket kan afspejles i indskrivningen af monstrøse træk i heltekarakteren. ${ }^{7}$ Et sidste eksempel kan hentes fra xenofobiske beskrivelser af bestemte grupper som monstrøse (f.eks. den nazistiske retoriks udsagn om, at jøderne åd børn og brugte deres blod i brødet, samt afbildningen af samme gruppe på propagandategninger), hvor det er karakteristisk, at vender man kameraet om, ser man straks forfølgernes egen monstrøsitet. I forfølgelsens udslettelsesiver ligner forfølgeren og monstret hinanden til forveksling. Hvis det er sådan de monstrøse strategier virker, hvilken funktion har monstrøsitet så i kulturelle diskurser?

Overvejes monstrenes funktion i sociale systemer, er der hjælp at hente hos den franske litterat René Girard. Han mener, at monstre demonstrerer klassifikationssystemers mulighed for at afvige fra deres faktiske udseende, det vil sige for at ophøre med at eksistere. De afslører den farlige sandhed, at systemer er relative, arbitrære og konstruerede (Girard 1982, 34f og 52-5). Angsten for ne pas différer du tout, for forskelsløsheden mellem os og de andre, udløser syndebukkemekanismen i kraft af hvilken forvrængninger og sammenblandinger af arter og genrer dannes (s. 71). Disse deformiteter kan være virkelige, men ofte sker det, at et offer af den gruppe, som har udvalgt det, tillægges svagheder og deformiteter, der bekræfter og forstærker offerpolariseringen. Derved fremstår monstrøsiteten, som om den var virkelig (s. 29f). Syndebukkemonstret ødelægges rituelt og renser derved fællesskabet ved at eliminere dets synder. Syndebukkens udslettelse kan fungere som exorcisme og - genfortalt - som katekisme (s. 49f, 75). På den måde kan monstrøsitetens funktion være bevarelse af socialitetens homogenitet og renhed (Cohen 1996, 12-20; Crook 1998, 532, 537). ${ }^{8}$

En sådan læsning af monstrøsitet fungerer udmærket, når fokus rettes mod monstrøsitet anvendt i og som kulturelle diskurser. Der er dog hovedsagelig to områder, hvorved en sådan læsning må suppleres. For det første redegør den ikke dækkende for monstrenes fascinationskraft. Monstrenes tiltrækningskraft kan måske forklares som en

afraid of having 'produced his own grave-diggers'. The monster's explicit demands cannot in fact produce fear ... The monster's sheer existence is frightening ... (Moretti 1983, 84-86).

${ }^{7}$ Helten antager ofte monstrøse træk (Girard 1982, 54). Mircea Eliade hævder om helte og monstre, at helten normalt adskiller sig ved sin styrke og skønhed, men faktisk også ofte ved monstrøse træk, anomalier osv. Eliade 1978, 301 .

${ }^{8}$ På trods af monstrets funktion som bevarelse af homogeniteten, kropsliggør det paradoksalt nok også med sit forstyrrende udseende den problemstilling, som det er med til at løse. Det grundlæggende problem, som monstre giver form til, er således problemet om, hvordan det sociales enhed fastholdes samtidig med, at dets mange forskellige former anerkendes. 


\section{Monstrøsitet som kulturel og religiøs diskurs}

længsel efter uhindret at tilegne sig det, man begærer. Ikke længere at tage hensyn til moralske aporier, sociale konflikter og uundgåelige kompromisindgåelser, at være uden kontrol over egne instinkter og lyster. Forstået på den måde udtrykker monstrets fascinationskraft en længsel efter en førsamfundsmæssig uskyld, efter en førcivilisatorisk naturtilstand eller en regressiv længsel efter et liv før individuationen samt i det omfang moralen er instinktfjendtlig en længsel efter at løse etiske dilemmaer med vold (Brittnacher 1994, 318f). Det er dog ikke mit fokus her.

Det er imidlertid det andet område, hvor en ren sociologisk læsning må uddybes. En sådan læsning står nemlig svagere, når det gælder monstre i religiøse diskurser, fordi den ikke behandler monstre i forhold til spørgsmålet om forandring af eksisterende realiteter, og heller ikke har blik for, hvordan monstrøsitet kan lades positivt. Af den grund vil jeg udfolde en læsning af monstrøsitet som religiøs diskurs, som efterfølgende belyses af materiale fra det gamle Mesopotamien.

\section{Betwixt and between: monstrøsitet som religiøs diskurs}

Monstret bebor det ukendte: margenernes, farens og fantasiens mørke egne. Af den grund kan det kropsliggøre muligheden af at se verden på en anden måde, muligheden af at omskabe verden, klassifikationerne og de kulturelle identiteter. Monstrets monstrøsitet, dets uklassificerbarhed, ${ }^{9}$ bidrager netop til, at det kan fremtvinge en gentænkning af, hvor de klassifikatoriske grænser skal gå, hvad 'normale' identiteter vil sige. Den "diskussion" eller gentænkning af de kulturelle klassifikationer, som monstret kan give anledning til, åbner muligheden for at se verden på en ny måde, at omskabe den. Anvendelsen af monstrøsitet i religiøse diskurser har ofte denne funktion. Monstret som fænomen kan dermed ses som en slags kropsliggørelse af fænomenet liminalitet. Det liminales transcendentale, transformative magt udtrykkes ofte med monstrøse symboler. Jeg vil her forsøge at vise, at monstre må forstås som mere end blot forstyrrende og farlige væsener, idet de også kan forstås som positive og venligtstemte væsener. Monstrets anvendelse i religiøse diskurser relaterer jeg til de Certeaus grænsetænkning og Turners liminalitetsteori. Det indebærer en udvidelse af liminalitetsbegrebet til at være mere end en fase i et ritual, nemlig udtryk for spatiale og konceptuelle strukturer og relationer.

\footnotetext{
${ }_{9}^{9}$ Diskussionen om monstre og klassifikationssystemer er velkendt i religionsvidenskaben. Ifølge Dan Sperber udfylder fantastiske dyr ikke hullerne i de eksisterende taksonomier, ej heller affødes de af disse taksonomier, men placeres snarere i opposition til dem. Dette synspunkt, at der eksisterer en forbindelse mellem visse dyrs symbolik og deres marginale karakter i den kulturelle taksonomi, deles af Mary Douglas og Claude Lévi-Strauss (for referencer samt en detaljeret diskussion, se Sperber 1975). Hybrider og monstre kombinerer træk fra arter og genrer, som er placeret langt fra hinanden i taksonomien. Hvis de udgør anomalier, skal de forstås som modsigelse til taksonomien, ikke som affødt af den (Sperber 1975, 5-16). Symbolsk repræsentation korrigerer ikke den rationelle taksonomi. Den efterlader den intakt. Den fremkalder en værre verden, anomaliens, og en bedre, exemplaritetens. "Elle donne à penser ce que le monde est, en contraste avec ce qu'il n'est pas” (Sperber 1975, 31). Når de principper, på hvilke klassifikationen af dyr er funderet, brydes, overskrides, omvendes, så sættes de repræsentationer, der er resultat af denne overskridelse, i parentes, og behandles symbolsk (Sperber 1975, 32).
} 
Arnold van Gennep lagde i det klassiske ritualstudium Rites de passage (1909) ansatserne til det liminalitetsbegreb, som Victor Turner (1969, 1973 og 1974) senere udfoldede. Den liminale fase, den midterste sekvens i et overgangsritual, i hvilken man er uden for det almindelige liv og mere direkte 'udsat for' det transcendente, ses som det afgørende led i ritualet, hvor transformationen i individets eller gruppens sociale, kulturelle eller psykiske tilstand finder sted. Denne liminale periode betegner en væren betwixt and between de almindelige kulturelle klassifikationer og kognitive kategorier. Liminalitet er ifølge Victor Turner hovedsageligt en temporær periode, en fase i et ritual, der involverer forandring (Turner 1977, 36-8; 1974, 231-3, 73f; Alexander 1991, 29-33). Det liminales transcendente og transformative magt kan udtrykkes i symboler. De er ofte kendetegnet ved forvridninger eller forandringer af almindelige kategorier og kroppe. Den mest karakteristiske liminale symbolik er paradoksets, sammenblandingens, en væren 'både og', f.eks. androgyne væsener, levende døde, menneskelignende dyr, dyrelignende mennesker og forskellige sammenblandinger af dyrearter (van Gennep 1909, 116f, 124, 161ff, 210f, 263-67; Turner 1977, 37f). Man kan således sige, at den liminale fase netop er det monstrøses og det unormales legeplads. Liminalitet kan imidlertid også forstås bredere end som en fase i et ritual, nemlig som en konceptuel størrelse, der udover at kunne materialiseres i temporære relationer også kan finde udtryk i f.eks. spatielle og aktionelle kategorier. En sådan udvidelse af begrebet om liminalitet vil være en fordel i forhold til forståelsen af monstrøsitet, og derfor vil jeg nu knytte nogle bemærkninger til den.

Monstrets anvendelse i religiøse diskurser kan ses i forbindelse med det religiøse fænomen portal. Portaler er steder, hvorigennem man træder ind i eller forlader et rum, og de implicerer et skel, en adskillelse. 'Indenfor' og 'udenfor' har i mange kulturer en række konnotationer: kendt-ukendt, sikker-farlig, hellig-profan. Portalerne er med til at definere overgangene og sætte grænser mellem forskellige betydningsrum. En portal er en grænseovergang forstået i en vis udstrækning, og den tematiserer den liminalitet, der kan præsentere nye værensmuligheder. Portaler kan være fysisk-spatialt markeret som et liminalt sted, eller en handling kan være markeret som liminal. De mest indlysende og dramatiske portaler er arkitektoniske (porte, døre, vinduer osv.), men i nogle religiøse traditioner ses også samlejet som en slags portal. Portalen definerer det sted, på hvilket man kan træde ind i den anden, sakrale verden eller blive udsat for/få adgang til dens transformative kræfter. Fra et sådant sted kan kræfter, positive såvel som negative, fra den anden verden trækkes ind i denne verden, og onde eller destruktive kræfter føres ud (MacDonald et al. 1989, 39-43, 46f, 53-5). Portalen og dens symbolik kan ses som orienteringspunkt, der hjælper kultpersonalet til at orientere sig i rum i forhold til den normale, profane verden. Den er således en slags adgangsvej til flere 'virkeligheder', og giver en spatielt eller handlingssekventielt markeret mulighed for kommunikation mellem det hinsidige og det dennesidige. Et interessant træk ved fænomenet portal er monstres hyppige forekomst som motiv på eller nær portalen. De ses enten som de overnaturlige, farlige væsener, der vogter den, eller som præstens eller shamanens vejvisere og hjælpere i 'den anden verden'. De kan forstås som en symbolsk afbildning af 
de farer, der er forbundet med overgangen mellem to virkeligheder, for krise, fare og risiko kendetegner passagen gennem en portal. Monstrene kan dog også udtrykke positiv hjælp og ledsagelse i den forbindelse, idet de som beskyttere eller vogtere tænkes at hjælpe eller lette overgangen mellem forskellige 'verdener'. Liminaliteten, der giver mulighed for forandring af eksisterende realiteter, kan altså materialiseres i både temporære, aktionelle og spatiale relationer. Det kan derfor med fordel forstås som et mere vidtrækkende begreb end udelukkende som en fase i et ritual.

Den monstrøse religiøse symbolik tematiserer forskellige rum, deres indbyrdes relationer og hvordan man bevæger sig imellem dem, kort sagt menneskets forhold til 'den anden verden', transcendensens stærke og transformerende kræfter. Monstre kan både fremstilles positivt, som venligsindede hjælpere, og negativt, som farlige fjender, fordi de kropsliggør adgangen til transcendensens stærke kræfter. Monstrets sammensathed korresponderer i religiøse diskurser med dets tilhørsforhold til to verdener, to ordener: en dennesidig og en hinsidig. Som deform og abnorm skabning er monstret ren overflade, men denne overflade henviser dog til noget andet. Afvigelsen er samtidig en udmoerkelse. Anomalien betegner monstrets relation til den anden verden, og således kan monstre italesættes som stigmatiserede pendlere mellem det hinsides og den reale verden. Disse pendlere kan så anvendes til at skabe forandring af eksisterende realiteter hidkaldelse af godt, bortsendelse af ondt. De bærer ingen værditilskrivning i og af sig selv, men kan anvendes både positivt og negativt. De er ikke automatisk skræmmende væsener, men netop liminale figurer, der kan anvendes i overgangsriter, markere særlige steder som portaler, handle i mytiske fortællinger osv. Konsekvensen af dette bliver en udvidelse af en mere antropologisk-sociologisk læsning af monstrets betydning, for det indebærer, at monstre må forstås som mere end blot forstyrrende og farlige væsener, idet de også kan forstås som positive og venligtstemte skikkelser. I det følgende vil jeg illustrere dette gennem en præsentation af udvalgte monstertraditioner fra det gamle Mesopotamien.

\section{Illustration: monstre i mesopotamiske religiøse traditioner}

Fra de gamle mesopotamiske kulturer fra de opdyrkede områder i Tigris- og Eufratdalene, der blomstrede $\mathrm{i}$ en periode fra cirka 5000 år siden til ca. 2500 år siden, kender vi mange forestillinger om monstre i både litteratur og kunst. Det drejer sig om de gamle sumeriske, babylonske og assyriske kulturer, som øvede stor indflydelse på andre kulturer i Nærorienten, inklusive de indbyggere i Palæstina, hvis religiøse verden senere blev udtrykt i den samling skrifter, vi kender som Gammel Testamente. Hvordan kan man imidlertid identificere kategorien monster i religiøse traditioner fra Mesopotamien?

En identifikation ud fra et eksternt perspektiv er forholdsvis uproblematisk - deres hybride, sammensatte, udseende gør dem lette at identificere. Hvad en intern definition angår, tilhører monstrene i Mesopotamien en gruppe af overnaturlige væsener, som netop ikke er guder. ${ }^{10}$ At de mesopotamiske lærde ikke klassificerede monstrene som

\footnotetext{
${ }^{10}$ Jeg gør opmærksom på, at der i assyriologisk forskning er opstået en i forhold til andre forskningstraditioner uklar terminologi, ifølge hvilken 'dæmoner' er alle oprejste menneske-hybride væsener, mens
} 
guder, ses blandt andet $\mathrm{i}$ en type tekster, som kun er repræsenteret $\mathrm{i}$ beskedent omfang $\mathrm{i}$ Mesopotamien, nemlig eksplicit 'teologiske' tekster. Teologisk tænkning, forstået som systematisering af egne religiøse traditioner, fandt i Mesopotamien udtryk i f.eks. de såkaldte 'gudelister'. ${ }^{11}$ I disse lister over guder optræder monstre ikke. Endvidere udstyres monstre kun meget sjældent med determinativen 12 for guddommelighed (diğir). I kunsten bærer de heller ikke mærket for guddommelighed, hornekronen. På trods af sådanne rimeligt klare distinktioner har de mesopotamiske sprog (sumerisk og akkadisk) ikke et ord for 'monster'. Man finder dog samletermer for overnaturlige væsener med monstrøs form som udug/rābisu $u^{13}$ ('vogter'), $\operatorname{alad}_{2} / \operatorname{lama}_{2} / \bar{s} \bar{e} d u$ og lamassu ('skytsvæsener', 'held'), u $\mathrm{u}_{4} / \bar{u} m u$ (ümu B, 'storm'), ú-ma-am/umāmu ('dyr'), šūt mê nāri u nābali ('vandets, flodens og kildens væsener'), binût apsî (apsûs skabninger), lahmu (oprindeligt et bestemt Mischwesen knyttet til havet, men i standardbabylonske ${ }^{14}$ tekster en betegnelse for monstre som sådan), og apkallu (en betegnelse for fiske-, fugle- og 'Gilgameš' lignende ${ }^{15}$ væsener). ${ }^{16}$

'monster' anvendes om dyrekombinationer på alle fire (se også Black and Green 1995, 63a). Den er uklar, fordi det netop ikke kun er menneskehybrider, der svarer til den sædvanlige brug af det græske daimon, for det gør dyrehybriderne også

${ }^{11}$ Eksempler på sådanne findes fra alle epoker. Fra den tidligste tid findes lister fra Fāra (2600 f.v.t.); senere har vi en oldbabylonisk liste fra Nippur, den store An=Anum (fra MA, mellemassyriske, manuskripter), emesal-listen (fra et sted mellem 1400 og 900) o.a. Gudelisterne afslører en klassifikatorisk vilje, som begyndte meget tidligt og fortsatte. Guderne blev inddelt i grupper, som hver tilknyttedes en stor gud, som guderne i gruppen var 'afhængig af' eller relateret til i en slags lagdelt pyramide. Det organisatoriske grupperingsprincip var ultra-antropomorft. Mindre guder knyttedes til de store guder som familie, ægtefæller, børn, personale.

${ }^{12}$ I kileskriften fungerer nogle tegn som grafiske indikatorer på en klasse af objekter, til hvilken det objekt, som et givet nomen denoterer, tilhører. Sådanne kaldes determinativer. De er fysisk umulige at skelne fra syllabiske tegn. Eksempler er dinğir-tegnet, som sættes foran gudenavne (o.a.); giš-tegnet, som sættes foran objekter lavet af træ; kur-tegnet, som sættes foran geografiske navne.

${ }^{13}$ Jf. 1 Mos 4, 7, hvor der tales om, at synden skal blive som en "lurer" ved døren. Ordet "lurer" er afledt af den samme rod som det akkadiske räbisu, der betegner et monster. I mesopotamisk religion opfattedes 'onde' monstre som agenter for gudernes vilje, og deres rolle var at udføre den guddommeligt sanktionerede straf for synd.

${ }^{14}$ Standardbabylonsk er en særlig lærd dialekt på akkadisk. Allerede fra kassitisk tid blev oldbabylonsk anset for at være den klassiske periode i akkadisk sprog og litteratur, og skriverne i både Assyrien og Babylonien forsøgte at kopiere det i en rent litterær (dvs. ikke-talt) dialekt, som assyriologer kalder standardbabylonsk. Skrivernes forsøg på at kopiere det klassiske sprog udmøntede sig på varieret måde, eftersom skrivernes egne dialekter og sprogmønstre påvirkede teksternes sprog. Standardbabylonsk er den dialekt, hvorpå vigtige værker som Enüma Eliš og den lange standardversion af Gilgamesh-epet er skrevet, samt faktisk alle de litterære tekster fra det sene 2. og det 1. årtusind, så vel som mange kongeindskrifter.

${ }^{15}$ Reiner 1961, 5 note 3 . Grunden til at de kaldes Gilgameš-figurer, selv om de som sådan intet har med figuren Gilgameš at gøre, er, at man i assyriologiens tidlige dage med lys og lygte søgte at identificere de figurer, man kendte fra myter og eper, i kunsten. Dette kom til udtryk i, at man identificerede f.eks. Gilgameš overalt i kunsten på et meget spinkelt grundlag (se f.eks. Smith 1876 og så sent som 1979 bogen Gilgameš og Enkidu (på russisk) af V.K. Afanasieva). Siden er det blevet vist, at disse figurer ikke havde meget med Gilgameš at gøre; se hertil f.eks. Lambert 1987.

${ }^{16}$ Alle disse termers brug varierer i tid og rum. De kan imidlertid ikke diskuteres individuelt her. 
Flertallet af disse samletermer kvalificeres yderligere som enten gode (damqu) eller onde (lemnu), hvilket viser, at de ikke i sig selv bærer en værditilskrivning. Selv nogle af de monstre, der inkluderes i listen over 'onde dæmoner', utukkū lemnūtu, kan i denne liste og andre tekster kvalificeres som f.eks. asakku lemnu (belæg i $\mathrm{AHw}^{17}$ 73a), udug $\breve{s a}_{6}$-ga eller ${ }^{d}$ lamma ša ${ }_{6}$-ga (Geller 1985, 22, 46f; Limet 1989, 22). Monstret var således ikke i sig selv ondt eller godt, det beroede på kontekst og brug. ${ }^{18}$

Ordet $\bar{u} m u$ fortjener et par bemærkninger i forbindelse med interne kategoriseringer, eftersom det har spillet en vis rolle i assyriologisk forskningshistorie. Det akkadiske ord ümu oversættes af Rittig (1977) med 'Geist'; men man ser også hos andre forfattere, f.eks. Green og Wiggermann, betegnelsen 'Spirit' i forbindelse med de mesopotamiske monstre. ${ }^{19}$ Disse oversættelser kan efter min mening betvivles. Hverken tekster eller ikonografien kan utvetydigt identificeres med de ånder eller åndelignende væsener, som oversættelserne 'Geist' og 'Spirit' indikerer. Det akkadiske ūmu (sumerisk $\mathrm{u}_{4}$ ) kan betyde 'storm' henholdsvis 'løve'/'Mischwesen' (sumerisk pirig ${ }_{2}^{20}$ ). Ordet bruges metaforisk i beskrivelser af kamp og krig, og kan også betegne et våben. Endelig brugtes ordet om et bestemt monster, ümu-monstret (Wiggermann 1992, 147ff; Westenholz 1996, 194f). I ritualteksten KAR $298^{21}$ (passim) fra det første årtusind anvendes ordet $\bar{u} m u$ gentagne gange med reference til forskellige monstre, f.eks. lerfiguriner af apkallu (transskription og oversættelse af teksten findes hos Rittig 1977 samt Wiggermann 1992), og det er tydeligt, at ordet fungerer som kategoriterm. Der er ikke noget, der tyder på, at vi utvetydigt har med ånder at gøre, ${ }^{22}$ og så længe der ikke argumenteres for

\footnotetext{
${ }^{17}$ Standardordbøgerne for akkadisk forkortes hhv. AHw: Akkadisches Handwörterbuch (W. von Soden 1965), og CAD: Chicago Assyrian Dictionary.

${ }^{18}$ Alle ovennævnte termer fortjener en selvstændig undersøgelse. Det er imidlertid ikke relevant her. De betegner alle en slags overnaturlige væsener, som ikke har guderang, men grænsen er flydende. Spørgsmålet om den enkeltes 'personlige, beskyttende gud og gudinde', ilu og ištar, en slags 'mindre guder' ikke helt af samme rang som 'de store guder', viser netop, at det er et spørgsmål om gradsforskelle. I et vist omfang kan man sige, at alle guderne i Mesopotamien, alle overnaturlige væsener, af hvilken rang de end måtte være, er lige vel i stand til at øve godt som ondt. Det gælder selv de største guder. Fra et internt perspektiv er der dog indskrevet en skelnen i det forhold, at alle de store guder fremstilles antropomorft, mens alle mindre, overnaturlige væsener fremstilles monstrøst (se desuden Limet 1989, 30).

${ }^{19}$ Jf. titlen på Wiggermanns bog, i hvilken ritualteksterne, der omtaler monstre, er udgivet: Mesopotamian Protective Spirits (Green 1983, 1984, 1986; Wiggermann 1992).

${ }^{20}$ Dette ord bruges allerede fra tidligdynastiske kongeindskrifter (f.eks. Enmetena) til at betegne apotropæiske vogtere ved døre i templer.

${ }^{21}$ Dette 'navn og nummer' henviser til en bestemt kileskriftstavle fra Assyrien udgivet af Erich Ebeling i serien Keilschriftstexte aus Assur Religiösen Inhalts.

${ }^{22}$ De eneste transempiriske væsener, som med god ret kan kaldes en slags 'ånder', er de afdødes ånder, nemlig etimmu, som levede en slags skyggetilværelse i underverdenen, kur-nu-gi ' the land of no return'. De afdøde skulle passes og behandles med respekt af de levende, gives rent vand, deres navne skulle "nævnes". Hvis de afdøde blev æret på passende vis, så kunne de være modtagelige for bønner, gå i forbøn for familien, fjerne lidelser og lignende. Men hvis de ikke æredes, ikke blev givet rent vand at drikke, så ville de plage de levende og sende dem alskens lidelser (Finet 1989, 48f). Bemærk, hvordan også disse er i stand til at øve både godt og ondt.
} 
brugen af 'Geist' og 'Spirit' bør man ikke oversætte $\bar{u} m u$ med 'Geist'/'Spirit'/'ånd', men snarere ud fra dets brug og udseende med f.eks. 'Mischwesen', “monster” eller evt. "overnaturligt/transempirisk væsen med begrænset magt". Det vigtige er, at monstret som kategori er let at skelne og forholdsvist konsistent reflekteret også fra et internt perspektiv i Mesopotamien.

Den følgende beskrivelse af monstertraditioner fra Mesopotamien består af udvalgte eksempler. De er kategoriseret først efter genre og dernæst kronologi. Først beskrives eksempler på monstre fra mytisk/narrative tekster, derpå eksempler fra ritualtekster og 'indskrifter', der behandles under et. 'Indskrifter' er de tekster, man har fundet graveret på de arkæologisk udgravede lerfigurer, hvis udseende og placering ritualteksterne beskriver. Ikonografiske fremstillinger af monstre diskuteres i øvrigt undervejs i det omfang, det er relevant.

I tidlige sumeriske episke traditioner spiller monstre en rolle som bipersoner i eperne om de tidlige sumeriske konger af Uruk: Enmerkar, Lugalbanda og Gilgameš. I Lugalbandaepet (Wilcke 1969) hjælper fuglemonsteret Anzu helten Lugalbanda, da han er faret vild i bjergene, som tak for at Lugalbanda har pyntet dens rede og taget sig godt af dens unger, mens den var ude at jage. Som belønning giver Anzu Lugalbanda en overnaturlig hurtighed i gave, der sætter ham i stand til at overbringe en vigtig besked til gudinden Inanna i Uruk. Anzu-monstret, i epet ofte blot kaldet 'fuglen' (mušen; Wilcke 1969,62 ), beskrives som et monster (Lugalbandaepet 1.47f, 1.99ff, hajtænder, ørnekløer, enorme vinger, med et næb som en sav og i stand til at afgøre skæbner), og er både frygtindgydende og hjælpsom (1.110-114). Anzumonstret er altså en flertydig skikkelse. I kunsten afbildes Anzû som en fugl med løvehoved i tidligdynastisk tid og associeres med guden Ninğirsu på Gribbestelen, og der henvises til Anzu i forbindelse med Ninğirsu i en af Gudea af Lagaš’ drømme. Denne forbindelse mellem Ninğirsu og Anzu stammer antagelig fra Ninğirsu/Ninurtas kamp mod og overvindelse af fuglemonstret (mere nedenfor). I Enmerkar/Lugalbanda-traditionerne er Anzû en ambivalent skikkelse og derfor ikke entydigt ond og truende. Bosat i den civiliserede verdens grænseområde, i 'kur", bjergene, med det formål at 'lukke bjergenes forside som en stor dør' (Lugalbandaepet 1.103) kropsliggør Anzumonstret magtfulde kræfter, der kan være skræmmende og truende, men som også kan anvendes positivt. Anzu tilvejebringer den positive forvandling af Lugalbanda, der er den igangsættende drivkraft i resten af epet. Desuden italesættes Anzu som grænsefænomen ('bjergenes dør' og liminal figur, som fremkalder forandring.

Monstret Huwawa er kendt fra historierne om Gilgameš, både i sumeriske og akkadiske versioner. ${ }^{23}$ Den basale gang i historien er, at helten Gilgameš og vennen Enkidu er på vej til cedertræsbjerget for at hente cedertræ. Cedertræsbjerget bevogtes imidlertid på foranledning af guden Enlil af monstret Huwawa, som Gilgameš og Enkidu dog overvinder ved hjælp af list og dræber, så de kan få cedertræ med hjem. I kunsten afbildes Huwawa typisk som en menneskekrop med løvekløer i stedet for

\footnotetext{
${ }^{23} \mathrm{Se}$ www-etcsl.orient.ox.ac.uk for tekst og referencer.
} 
hænder og et monstrøst ansigt (forstørret mund, øren, øjne, "troldeagtig”) med langt hår og kort skæg. Huwawa er den legitime vogter af et grænseområde, og drabet på ham skildres som en art hybris, en illegitim overtrædelse af det menneskelige handlerums grænser.

Ligeledes er Himmeltyren, som er af monstrøs størrelse, kendt fra Gilgamešhistorierne. ${ }^{24}$ Et skænderi opstår mellem gudinden Inanna og Gilgameš, da han afviser hendes seksuelle tilnærmelser, så hun får den overnaturlige tyr sendt ned fra himlen med henblik på at ødelægge ham og hans by. Men Gilgameš og vennen Enkidu viser sig på højde med situationen og får dræbt Himmeltyren, hvilket bliver straffet af guderne. Himmeltyren er Inannas legitime hjælper, og drabet på den opfattes derfor som hybris. Guderne beslutter, at Enkidu må dø.

De sumeriske mytiske traditioner relateret til helteguden Ninurta/ Ninğirsu ${ }^{25}$ associerer monstre med farlige og oprørske bjerge, ${ }^{26}$ således kompositionerne ${ }^{27}$ Lugale og Angimdimma. Lugale handler om, hvordan Ninurta efter at have kæmpet mod bjergmonstret Azag ordner bjergene, floden Tigris’ løb, vandingssystemerne med mere og udtaler forbandelser og velsignelser over Azags børn, stenene. Azag fulgtes nemlig af en hær af (monstrøse) stenhjælpere (van Dijk 1983). Angimdimma handler om Ninurtas triumferende hjemkomst til sin by Nippur og hans indtog i templet Ešumeša. Ninurta, besejreren af kur (bjergene, de fremmede lande) og ki-bal (de oprørske lande), smykker her sit køretøj med sejrstrofæer og kampregalia og sætter kurs mod Nippur, hvor han efter at have krævet en lovprisning fra sin far Enlil drager til sit tempel Ešumeša (Cooper 1978). Angimdimma rummer en beskrivelse af disse 'trofæer': de monstre, som han overvandt i bjergene. 'De slagne Helte' kaldes de monstre, som anses for at være blevet dræbt af Ninğirsu/Ninurta. ${ }^{28}$ Myten om drabet på disse monstre, hvoraf nogle er dyrehybrider, andre ting-hybrider, kan spores tilbage til Gudeas tid, hersker af Lagaš. Han genopbyggede Ninğirsus tempel i Girsu og sørgede for, at 'de slagne Helte' modtog ofre i Ninğirsus nye tempel (Gudea Cyl. A xxv-xxvi; Black 1988). Det er tydeligt, at guden Ninurta var monsterbekæmperen par excellence i disse mytiske traditioner, der beskriver monstrene ved hjælp af samletermerne 'slagne helte', 'fangne krigere og konger', 'fangne vildtyre og -køer' (sumerisk: ur-sag ug $_{5}$-ga, ur-sag dab -ba $^{-}$

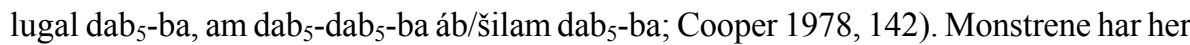

\footnotetext{
${ }^{24}$ Jf. den sumeriske "Gilgameš og Himmeltyren" og det senere standardbabylonske Gilgameš-epos' 6. tavle. De sumeriske tekster med referencer kan findes på www-etcsl.orient.ox.ac.uk

${ }^{25}$ Ninğirsu, hvis navn betyder 'Girsus Herre', er en gud for vegetation og krig, som var magtfuld i Lagašområdet, og han identificeredes med Ninurta.

${ }^{26}$ I Mesopotamien de fysisk-geografiske randområder for det mesopotamiske kerneland mellem floderne, og således er bjergområderne oplagte kandidater til posten som "civilisationens udpost og grænse". Allerede kongeindskrifter fra det 3. årtusind (f.eks. Utu-hegal-indskriften; se Römer in Orientalia 54, 1985, 276) refererer til kur som fjendernes hjemsted.

${ }^{27}$ De to kompositioner indeholder mytisk materiale, men indeholder også så store dele af hymnisk materiale, at man nok skal tøve med ligeud at kalde dem 'myter'. Se Cooper 1978, 4.

28 Den Sekshovedede Vildbuk, Den Syvhovedede Slange, Dragen, Palmetræs-kongen, Gypsum, Stærk Kobber, Kuli-ana, Magillum-båden, Herren Saman-ana, Bison-Tyren og Anzu-fuglen.
} 
en fjendtlig og truende rolle, ${ }^{29}$ og bebor 'bjergene', den fantasmatiske grænseegn, og behandles som 'byggemateriale' i Ninğirsu/Ninurtas ordning af (den del af) verden. En yderligere myte, overleveret både på old- og standardbabylonsk, er historien om, hvordan Ninurta overvandt fuglemonstret Anzû. ${ }^{30}$ Anzû havde stjålet Skæbnernes Tavle fra guden Enlil og bragt den ud til sin bolig i bjergene, hvorved verdens normale orden bringes i uorden. ${ }^{31}$ I denne myte fremstilles Anzû som et truende og skræmmende monster med onde hensigter, men det er værd at bemærke, at dette monster kun kunne stjæle Skæbnernes Tavle, fordi det oprindeligt var guden Enlils legitime dørvogter.

En senere udvikling, der finder sted i løbet af det andet årtusinde, forbinder monstrene med havet, der således erstatter bjergene som geografisk orienteringspunkt (Wiggermann 1993). Ninğirsu/Ninurta-mytologien øvede i løbet af det 2. årtusind indflydelse på den del af monstermytologien, som er relateret til guden Marduk. Det sker særligt i den berømte skabelsesmyte Enūma eliš, hvor Marduk bekæmper Tiamats (det personificerede hav) monstrøse hær af onde og farlige monstre. Tiamats elleve monstre har mange ligheder med Ninurtas slagne fjender, og der kan i visse henseender argumenteres for en bevidst overtagelse af Ninurtamytologi (Lambert 1986). Monstrenes navne er mušmahhu, ušumgallu, bašmu (tre typer af slanger med horn), mušhuššu (slangedrage), lahmu (muligvis en langhåret heltefigur), ${ }^{32}$ ugallu ('Store Stormbæst', løve-menneske-hybrid), uridimmu ('Rasende Løve', løve-menneske-hybrid), girtablullu (skorpionmand), ümu dabrūtu (Rasende Monstre eller Stormbæster), kulullû (fiskemand), kusarikku (tyre-mand). ${ }^{33}$ Alle disse dræbes af guden Marduk i et stort slag (Enūma Eliš tavle IV). ${ }^{34}$ Flertallet af disse monstre bruges også i apotropæiske ritualer (se nedenfor samt Green 1997, 144). Til sidst dræbes monstrenes herskerinde Tiamat, det salte vand, som i øvrigt skifter mellem at være havet og et firbenet monster (se også Lambert 1986), og af hendes krop skabes den kendte verden.

Hertil kommer endnu en betydningsfuld mytisk tradition, der nævnes af Berossos, en Mardukpræst i Babylon i hellenistisk tid, som i sin Babyloniaca fortæller om otte fiskemonstre fra Oannes til Odakon (se Burstein 1978), som opstod af havet og belærte menneskeheden om civilisationens teknikker. Den antediluvianske viden om civilisation og kultur, som fiskevismændene kropsliggjorde, værdsattes højt og vurderedes meget positivt af babylonerne og assyrerne, som W.G. Lambert også understreger $(1962,72)$. Sandsynligvis kan Oannes identificeres med Adapa, en vismand 'fra gamle dage', som

\footnotetext{
${ }^{29}$ Monstrenes rolle er fjendens, men visse af dem er svære at forene med en rolle som fjende (f.eks. Magillum-båden, Stærk Kobber).

${ }^{30}$ Forskellen i stavemåde (Anzu/Anzû) dækker over en forskel i sprog (sumerisk/akkadisk).

${ }^{31}$ Myten findes i de fleste samlinger af myter fra Mesopotamien, således f.eks. Dalley 1991; Bottéro 1989; kileskriftsudgave, se Annus 2001.

32 Til diskussionen om lahmu'ens væsen, se Wiggermann 1988, Heimpel 1998 og Green 1997, 138.

${ }^{33}$ Bemærk, at tre af disse termer mušmahhū, ušumgallū nadrūtu, ūmū dabrūtu muligvis er generiske beskrivelser, således Lambert 1986, og de resterende otte egentlige specifikke monstre.

${ }^{34}$ Teksten er tilgængelig i oversættelse i alle samlinger af mytologiske tekster fra Mesopotamien. Kileskriftstekst i Lambert og Parker 1969.
} 
blev kaldt apkallu, og derfor kan man antage en vis forbindelse til de fiske-'klædte' figurer i kunsten, som også kaldes apkallu (Lambert 1962, Green 1984, samt se nedenfor). Berossos' fortælling har klare forbindelser til traditionerne om de syv (det mere almindelige antal) apkalle, 'vismænd fra før vandfloden'. Disse traditioner er imidlertid kun antydet i akkadiske tekster; intet udførligt materiale er bevaret. I Erraepet ${ }^{35}$ I, 147 og 162 får guden Marduk 'disse vise mænd til at gå ned til apsû' (I, 147), og siden begræder han deres fravær: "hvor er de syv vise fra apsû, de rene purādu-fisk, som ligesom deres herre Ea besidder enestående visdom?" (I, 162). Teksten LKA 76 rev., en tekst, der alternerer mellem besværgelser og rituelle anvisninger (Reiner 1966), nævner "de syv strålende apkallu, havets purädu-fisk, de syv apkallu, der er opvokset i floden, og som sikrer himlens og jordens planers ${ }^{36}$ korrekte fungeren". Den græske version fra Berossos afspejler en mytisk-narrativ tradition, der ikke korresponderer direkte med nogen akkadisk tekst, som nævner vismændene. En sådan myte har muligvis eksisteret, men har ikke overlevet på akkadisk, og det eneste, man har, er de nævnte indforståede henvisninger. Denne kortfattethed eller indforståethed viser dog tydeligt en mytisk-narrativ tradition om fiskemonstre som besiddere af uforlignelig visdom. Det er en monstertype, som er venligsindet over for mennesker, idet den bringer kulturel knowhow og civilisatoriske teknikker til mennesket og som derfor opfattes positivt.

Fiskemonstre beskrives også i rituelle tekster, som nævner en gruppe på syv apkall $\bar{u},{ }^{37}$ "vismænd"; fredelige, venligsindede væsener af fiskehybrid type, der skulle begraves under gulvet i private huse. Teksterne angiver, at væsenerne er monstrøst, det vil sige halvt mand, halvt karpe, snarere end en fiskeklædt person, sådan som det blev forstået tidligere, og som det synes fremstillet ikonografisk (Wiggermann 1992, 76). ${ }^{38}$ Teksterne beskriver, hvordan lerfigurerne af disse fiskemænd ser ud, og hvordan de skal anvendes i ritualet. Det vil f.eks. sige, at det angives, hvilken besværgelse der skal siges over dem, og hvor de skal begraves. Fiske-apkallu'en, som den fremstilles i kunsten, er en skægget mand, der bærer en fisk på sin ryg som en kappe, mens fiskens hovede er trukket henover hans eget hovede som en slags hat uden dog at skjule ansigtet. Nogle

\footnotetext{
${ }^{35}$ Erraepet handler om hvordan landet lider under pestguden Erras plagen i guden Marduks fravær. Da Marduk vender tilbage, hører det op. Epet findes i oversættelse hos Bottéro 1989. Se også AMT 105, 22 (se Lambert in Journal of Cuneiform Studies 11, 8), en kort henvisning til 'vismændene fra før vandfloden'.

${ }^{36}$ Oversættelsen 'planer' dækker over et centralt begreb i de mesopotamiske religioner. I mytologien siges de højeste guder, sædvanligvis An, Enlil og Enki, at have 'bestemt skæbnerne' eller 'fastlagt bestemmelserne' for alting. Her er det vigtigt at understrege, at det at guderne fastlagde en bestemmelse snarere var en afgrænsning af potentialiteter end et spørgsmål om prædetermination. Der var planer, 'tegninger', bag alting i verden, men disse skulle altid aktualiseres af verdens beboere, der også skulle arbejde med på realiseringen af den rette orden. De kosmiske bestemmelser opfattedes som indskrevet på en tavle, den benævnte Skæbnernes Tavle, som var i gudernes besiddelse. Se videre Alster 1974; Farber 1987-1990, Rochberg-Halton 1982 for diskussioner af ordene me, ğiš-hur og dub nam-tar-ra.

${ }^{37}$ Teorien om, at disse fiskemonstre skulle være de samme som nævnes af Berossos, er først fremsat af Zimmern, se Zeitschrift der Assyriologie 35, $151 \mathrm{ff}$.

${ }^{38}$ For referencer til tekster, der omtaler apkallu'ens udseende, se Foster 1974, 349, note 21.
} 
gange holder han en renselsesstav og en spand; andre gange skuddet af en dadelpalme i en hånd og den anden på brystet (Wiggermann 1992, 48).

Arkæologer har fundet små figuriner lavet af ler af dette væsen; de kaldes binût Apsê, 'Apsû's væsener', og sammen med andre figuriner șalmū sākip lemnūti ša Ea u Marduk, det vil sige "statuerne [billederne, figurerne], der jager de onde væk, Eas og Marduks". De blev fundet begravet i private rum (Wiggermann 1992, 65; van Buren 1930, nr. 192, 994 og 995; Rittig 1977). Det, der her siges om fiske-apkallu'er, gælder for størstedelen af monstrene, for de er blevet identificeret med deres repræsentationer $\mathrm{i}$ kunsten og parret med udgravede lerfigurer på basis af sådanne standardbabylonske ritualtekster, der omhandler beskyttelsen af et hus eller palads mod indtrængende ondt ved magiske midler (Rittig 1977; Green 1983, 87-96).

Disse rituelle tekster relateret til monstre er blevet udgivet af assyriologen F.A.M. Wiggermann (1992). Teksterne beskriver, hvordan et antal monstrøse lerfigurer skal formes og begraves på bestemte steder i huset (hjørner, indgange, trapper, baderum). Nogle få eksempler inkluderer mušhuššu, den 'Rasende Slange' (slange + løve), urmahlullû, 'Løvemanden' (løve + mand), kusarikku, 'Tyren/Oksen' (tyr/okse med menneskehænder), girtablullû, 'Skorpionmanden' (skorpion + mand), suhurmāšsu, 'Fiskegeden' (karpe + ged), apkallu' en og mange andre. Monstre ses også på relieffer langs med væggene i nyassyriske paladser eller som statuer ved portene til templer og paladser (Reade 1979, 17-49, Madhloom 1969, 94f)

Også nyassyriske kongetekster har givet en vis information om monstrenes udseende, formål og placering (Engel 1987). Det er tydeligt, at denne ikonografi og ritualerne knyttet dertil havde officiel status i religionen i det første årtusinde, som er den periode, denne kunst stammer fra. Det er værd at hæfte sig ved monstrenes placering i døre, porte, baderum og hjørner som markører på spatial liminalitet, og endvidere hvordan flere af de monstre, der fremstilles 'fjendtligt' i de narrative tekster, anvendes med positiv effekt i ritualerne. Dette ses også af de indskrifter, som ritualteksterne angiver skulle graveres på siden af de små monsterfiguriner lavet af ler. Disse indskriftsanvisninger er blevet bekræftet ved fund af figurer med indskrifter, der svarer til ritualanvisningerne. Her gengives et udvalg af sådanne:

erba tašmû u magāru, "kom ind, høren og velvilje" (KAR 298 rev. 4f, skrives på Fiskeged, suhurmāšu); rida hișib šadî, "stig ned, bjergenes overflod" (KAR 298 rev. 6f, på Fiskemand, kulullû); erba šulmu "kom ind, godt helbred" (KAR 298 rev. 1f, på Slange, bašmu); erba balātu "kom ind, liv!" (KAR 298 obv. 45f, på Tyr(emand), kusarikku); mušéribu damqāti "lykkebringer" (KAR 298 rev. 17f, på Den gale Hund, kalbu); ümu hegalli "frugtbarheds-monster" "39 (KAR 298 obv. 6f, på (fiske-vismand, apkallu), ușuh murșa erba mašrû, "riv sygdommen ud, kom ind, velstand" (på ušumgallu, drageslange, KAR 298 rev.)

\footnotetext{
${ }^{39}$ Min oversættelse 'monster' dækker over det akkadiske ord $\bar{u} m u$.
} 
Bemærk, at det ikke kun er de monstre, der er menneske-dyr-hybrider, som anvendes positivt, men også rene dyr-dyr-hybrider (f.eks. fiskegeden, slangen, drageslangen osv.). ${ }^{40}$ Ovenstående var imidlertid kun den ene side af mulige indskrifter. Der findes nemlig også indskrifter som:

sī lumun ... "gå ud, ondt!" (KAR 298 rev. 4f på Fiskeged, suhurmā̌su); și mūtu "gå ud, død!" (på Tyr(emand, kusarikku); taparrik mukīl rēš lemutti "du fordriver det ondes understøtter" (på urmahlullû, KAR 298 rev. 15f), mutīr irat lemni “den, der får den onde person til at flygte"; kāšid lemni ayyābi "den der fanger den onde person og fjenden"; sākip gallê lemnūti "den der afværger de onde dæmoner" (KAR 298 obv. 41f, på "løve dæmonen”, ugallu); mušēșu lemuttim "den der fører det onde ud" (KAR 298 rev. 17f, på den gale Hund, kalbu).

Her vil jeg påpege, hvordan monstrene anvendes netop med henblik på forandring af eksisterende realiteter, og hvordan deres funktion er relateret til på den ene side fremskaffelse eller sikring af transcendensens positive aspekt (godhed, helbredelse, liv), og på den anden side bortsendelse af dens negative aspekt (ondskab, sygdom, død).

Efter denne beskrivelse af udvalgte monstertraditioner fra Mesopotamien, er det på sin plads at drøfte, hvorledes de forskellige traditioner illustrerer monstrøsitet som religiøs diskurs. Først er det dog nødvendigt at behandle den internt assyriologiske diskussion af monstrøsitet og forholdet mellem monstre og guder. Det første, fordi nogle af monstrenes navne tilsyneladende er usammensatte, det vil sige antyder en ikkehybrid karakter. Det forhold er baggrunden for, at assyriologen F.A.M. Wiggermann (1992) på grundlag af de akkadiske og sumeriske monsternavnes etymologi hævder, at monstrene repræsenterer oprindeligt simple, almindelige dyr, som 'står for' ærefrygtindgydende naturfænomener, og som har fået monstrøs form for at kunne udtrykke denne ærefrygtindgydende kvalitet (Wiggermann 1992, 147-54). Hertil må man sige, at visse af navnenes usammensatte karakter ikke er tilstrækkelig grund til at se bort fra monstrenes faktiske hybride karakter. Der ligger en teoretisk fejltagelse i at ligestille etymologi med mening. Betydning afgøres ud fra brug, ikke ud fra etymologi, så det faktum, at monsternavnet indikerer et ikke-sammensat dyr er ikke nødvendigvis et signal om monstrets aktuelle betydning. Man kan også spørge, om de fænomener, der klassificeres som 'naturfænomener', udgør en kohærent klasse og med hvilken ret de 'automatisk' opfattes som ærefrygtindgydende?

Hvad angår det andet punkt, forholdet mellem monstre og guder i Mesopotamien, er der visse 'uldne kanter'. Flertallet af guderne i Mesopotamien og alle de store guder er entydigt antropomorfe. Dog har et beskedent antal guder hybrid form. Det forhold, at nogle monstre synes tilknyttet een bestemt gud (f.eks. er alle fiskemonstrene (suhurmāšu, kulullû, apkallu) relateret til ferskvandsguden Enki) har fået visse assyrio-

\footnotetext{
${ }^{40}$ Det siges nogle gange, at det er menneske/dyr-hybrider, som er velvillige væsener, mens dyr/dyr-hybrider er farlige og skræmmende. Sådan var det ikke i Mesopotamien: Her finder vi, at begge typer af monstrøsitet kan antage en positiv henholdsvis negativ ladning. Dette støtter tesen om, at monstret ikke bærer nogen værditilskrivning i sig selv, men at de kan anvendes både negativt og positivt.
} 
loger (Agnès Spycket, Thorkild Jacobsen) til at foreslå, at monstrene kunne være tidligere, mere oprindelige udgaver af de antropomorfe guder. Således skulle f.eks. Anzû-monstret være en tidligere, mere oprindelig konceptualisering af guden Ninurta. Dette er meget omdiskuteret (Lambert 1997, 2). Dog må der have eksisteret en forbindelse mellem monstrene og de guder, som nogle af dem var tilknyttet. Det kan imidlertid også forklares ad anden vej, f.eks. ved at de har samme virkedomæne, hvorved der etableres en association. Der er ikke nogen tvingende nødvendighed i antagelsen om at sådanne hybride, theriomorfe gudekonceptualiseringer skulle udgøre mere oprindelige versioner af guderne i Mesopotamien. Tværtimod er det tydeligt helt fra de allertidligste vidnesbyrd at de store guder både i sumerisk og akkadisk tradition fremstilledes og italesattes antropomorft.

I de mytisk/narrative traditioner om monstre opfattes monstrene hovedsagelig som truende væsener, som besejres og dræbes af en yngre gud (Ninurta, Marduk) eller en helt (Gilgameš/Enkidu). I Lugalbandaepet så vi dog Anzu-monstret som en ambivalent skikkelse; en skræmmende, men velvillig hjælper, der brugte sine mægtige og potentielt destruktive kræfter til at hjælpe Lugalbanda. Anzus spatiale lokalisering var bjergene, det vil sige civilisationens og den ordnede verdens grænseland ifølge flodlandsbeboerne, mesopotamierne. Monstret Huwawa var også bosat i et fantasmatisk grænseland, hvor han fungerede som retmæssig vogter af cederskoven. Ligeledes var Himmeltyren en legitim hjælper for gudinden Inanna, men dens destruktive kraft brugtes i fortællingen imod mennesket. Himmeltyren var desuden mere af en grænsegænger, idet den passerede fra himmel (hinsides) til jord (denne verden). I traditionerne relateret til Ninurta (Lugale, Angim, De Slagne Krigere, Anzû-epet) boede alle monstrene i grænselandet, i bjergene, men kunne dog hjembringes til templer som trofæer. Monstrene er her onde, destruktive modstandere, hvis døde kroppe kan anvendes som byggemateriale ved skabelsen af den ordnede verden. Monstertraditionerne relateret til Marduk afbilder ligeledes monstrene som onde og destruktive modstandere, af hvis kroppe den ordnede verden kan bygges. Vi så dog også narrative traditioner, i hvilke monstrene opfattes som venligsindede væsener, nemlig myten om De Syv Vise, der er menneskets venlige hjælpere, som besidder en viden 'fra før vandfloden' (dvs. en urtidsviden, fra før denne verden blev til). De pendlede hver dag fra urtidselementet (hinsides), nemlig havet, til landjorden (denne verden).

Ritualerne og de dertil forbundne indskrifter på de udgravede lerfigurer afslørede monstrene som tydelige markører af spatial liminalitet. De skulle begraves netop på liminale steder: hjørner, porte, døre, baderum. Indskrifterne gav oplysning om deres anvendelse og funktion. Her så vi, at de anvendes som pendlere mellem det 'hinsides' og 'denne verden', idet de kropsliggør den liminalitet, der kan give adgang til transcendensens transformative kræfter, positive så vel som negative.

Konsekvensen af disse læsninger af udvalgte mesopotamiske monstertraditioner bliver en udvidelse af en mere antropologisk læsning af monstrets betydning. De indebærer, at monstre må forstås som mere end blot forstyrrende og farlige væsener, idet de kan italesættes positivt i mesopotamiske religiøse diskurser, i såvel narrative 
som rituelle tekster. Det mesopotamiske materiale har desuden vist, at det giver god mening at forstå monstre som grænsefænomener, der kropsliggør liminalitet.

\section{Konklusion}

Aktuelle antropologiske monsterlæsninger giver gode redskaber til at læse monstrøsitet som kulturel diskurs, men står svagere, når det gælder analysen af monstre anvendt $\mathrm{i}$ religiøse diskurser, hvor monstrene fokuserer på menneskets relation til transcendensen: bevarelse/hidkaldelse af velsignelse og liv på den ene side, ødelæggelse/afværgelse af destruktion/forbandelse og død på den anden. Vi kan i lyset af det mesopotamiske materiale se, at et vigtigt aspekt er underbelyst i nutidens antropologiske monsterlæsninger, nemlig monstrøsitet brugt som instrument for og adgang til transcendensen, eller med en alternativ formulering: monstret som kropsliggørelse af liminalitet - en kropsliggørelse, der kan anvendes til at forandre det eksisterende. I det gamle Mesopotamiens religion og kultur spillede monstrøsiteten både en positiv og en negativ rolle. Netop dette viser, at liminaliteten er en god tankefigur at anvende i denne forbindelse, for liminaliteten kan stå for det rum, hvor forskelle ophæves, hvor alle katte bliver grå, hvor verdens vanlige orden er ophævet, og hvor forandring er mulig. Ud af denne liminale suppe kan så trækkes både destruktion og død og konstruktion, skabelse og liv. Det liminale rum selv er formbart, hverken-eller, både-og, og monstrene som kropsliggørelser af liminalitet kan derfor italesættes og anvendes som både gode og onde.

Ifølge Girard er det, vi frygter, at blive væk i forskelsløsheden, at blive borte i det kaotiske urhav, hvor de essentielle forskelle er udvisket, hvor identiteten mistes. Afsløringen af systemets ustabilitet er farlig, og derfor må monstret forfølges, jages, dræbes. Den vedblivende fascination af monstret viser imidlertid, at vi også længes efter den anden side af den store forskelsløshed, nemlig erfaringen af at høre til, en tilstand før individuation, samfund og civilisation, præget af længsel efter en forskelsløs opgåen $i$ altet. Monstrets opløsning af forskelle og den resulterende forskelsløshed tematiserer desuden altings potentialitet og muligheden for tilblivelse af noget nyt, muligheden for forandring af eksisterende realiteter. Monstrenes monstrøsitet bringer således en grænseudviskende uklarhed i spil, der vedblivende vil spørge til vore kulturelle kategoriseringer og identiteternes skrøbelige grænser.

\section{Litteratur}

AfANASIEVA, V.K.

1979 Gilgameš og Enkidu, (Гилбгамеш и Знкиду), Moskva.

ALEXANDER, B.

1991 Victor Turner Revisited: Ritual as Social change, Atlanta.

ALSTER, B.

1974 "On the Interpretation of 'Inanna and Enki'”, Zeitschrift der Assyriologie 64, 20-34.

ANNUS, A.

2001 The Epic of Anzîu, The Neo-Assyrian Text Corpus Project, Helsinki. 
BLACK, J.

1988 "The Slain Heroes. Some Monsters of Ancient Mesopotamia", Society for Mesopotamian Studies Bulletin 15, 19-25.

BLACK, J. \& A. GREEN

1995 Gods, Demons and Symbols of Ancient Mesopotamia, Austin.

Black. J., G. Cunningham, E. RobSon \& G. ZÓLymi

1998- The Electronic Text Corpus of Sumerian Literature, www-etcsl.orient.ox.ac.uk

BOTTÉRO, J.

1989 Lorsque les dieux faisaient l'homme, Paris.

1990 "Magie A." Realleksikon der Assyriologie 7 [1987-1990], Berlin, 200-34.

BOYER, P.

1994 The Naturalness of Religious Ideas, Berkeley.

2001 Religion Explained, London.

BRITTNACHER, H.R.

1994 Ästhetik des Horrors, Frankfurt a.M.

BUREN, E.D. VAN

1930 Clay Figurines of Babylonia and Assyria, Yale Oriental Series XVI, New Haven.

BURSTEIN, S. M.

1978 Babyloniaca of Berossos, Sources and Monographs, Sources from the Ancient Near East $\mathrm{I} / 5$, Malibu.

Certeau, M. DE

1984 The Practice of Everyday Life, overs. Steven Rendall, Berkeley.

COHEN, J.J.

1996 "Monster Culture (Seven Theses)" J.J. Cohen, ed., Monster Theory. Reading Culture, Minneapolis, 3-25.

COOPER, J.S.

1978 "The Return of Ninurta to Nippur. an-gim dím-ma", AnOr 52, Rom.

CROOK, S.

1998 "Minotaurs and Other Monsters", Sociology 32, 523-40.

Curran, A., R.P. MACCUBbin \& D.F. MorriLl, eds.

1997 Faces of Monstrosity in Eighteenth-Century Thought, special issue of EighteenthCentury Life, vol. 21, n.s., 2.

DALLEY, S.

1991 Myths from Mesopotamia. Creation, the Flood, and Others, Oxford.

DIJK, J. VAN

1983 LUGAL UD ME-LÁM-bi NIR-GÁL. Le récit et didactique des Travaux de Ninurta, du Déluge et de la nouvelle Création, Leiden.

ELIADE, M.

1978 Histoire des croyances et des idées religieuses I, Paris.

ENGEL, B.

1987 Darstellungen von Dämonen und Tieren in assyrischen Palästen und Tempeln nach den schriftlichen Quellen, Münchengladbach.

FARBER, G.

1987-1990

"me", Realleksikon der Assyriologie 7, Berlin, 610-13. 
FARKAS, A.E., O.P. HARPER \& E.B. HARRISON, eds.

1987 Monsters and Demons in the Ancient and Medieval Worlds. Papers Presented in Honor of Edith Porada, Mainz am Rhein.

FINET, A.

1989 "Les anges gardiens du Babylonien”, J. Ries og H. Limet, eds., Anges et Démons. Actes $d u$ Colloque de Liège et de Louvain-La-Neuve, 25-26 novembre 1987, Homo Religiosus 14, Louvain-La-Neuve.

FosTer, B.

1974 "Wisdom and the Gods in Ancient Mesopotamia", Orientalia NS 43, 344-54.

GELLER, M.J.

1985 Forerunners to Udug hul, Freiburger altorientalische Studien 12, Stuttgart.

GENNEP, A. VAN

1909 Les rites de passage, Paris.

GIRARD, R.

1982 Le bouc émissaire, Paris.

GreEN, A.

1983 "Neo-Assyrian Apotropaic Figures", Iraq 45, 87-96.

1984 "Beneficient Spirits and Malevolent Demons. The Iconography of Good and Evil in Ancient Mesopotamia”, Visible Religion, Vol. III, Popular Religion, Leiden, 80-105.

1986 "A Note on the Assyrian 'Goat-Fish', 'Fish-Man', and 'Fish-Woman'”, Iraq 48, 25-30.

1993 "Mischwesen B”, Realleksikon der Assyriologie 8, Berlin, 246-64.

1997 "Myths in Mesopotamian Art", I. Finkel og M. Geller, eds., Sumerian Gods and Their Representations, Groningen.

HEIMPEL, W.

1998 “Anthropomorphic and Bovine Lahmus”, M. Dietrich and O. Loretz, eds., dub-sar-antamen, FS Römer, Münster.

Klostergaard Petersen, A.

1998 "Shedding New Light on Paul's Understanding of Baptism: a Ritual-Theoretical Approach to Romans 6", Studia Theologica 52/1, 3-28.

KRITZMAN, L.D.

1996 "Representing the Monster: Cognition, Cripples, and Other Limp Parts in Montaigne's "Des Boyteux", J.J. Cohen, ed., Monster Theory. Reading Culture, Minneapolis, 168-82.

LACAPRA, D.

1983 "Bakhtin, Marxism, and the Carnivalesque", Rethinking Intellectual History: Texts, Contexts, Language, Ithaca.

LAMBERT, W.G.

1962 "A Catalogue of Texts and Authors", Journal of Cuneiform Studies 16/3, 59-77.

1986 "Ninurta Mythology in the Babylonian Epic of Creation", W. Sommerfeld og K. Hecker, eds., Keilschriftliche Literaturen, Ausgewählte Vorträge der XXXII. Rencontre Assyriologique Internationale, Münster, 1985, Berlin.

1987 "Gilgamesh in Literature and Art. The Second and First Millennia", Farkas, Harper og Harrison, eds., Monsters and Demons in the Ancient and Medieval Worlds. Papers Presented in Honour of Edith Porada, Mainz.

1997 "Sumerian Gods: Combining the Evidence of Texts and Art", Finkel and Geller, eds., Sumerian Gods and Their Representations, Groningen.

LAMBERT, W.G. \& S.B. PARKER

1969 Enuma Elish. The Babylonian Epic of Creation. The Cuneiform Text, Oxford. 
LIMET, $\mathrm{H}$.

1989 "Les Démons Méchants de la Babylonie", J. Ries og H. Limet, eds., Anges et Démons. Actes du Colloque de Liège et de Louvain-La-Neuve, 25-26 novembre 1987, Homo Religiosus 14, Louvain-La-Neuve.

MacDonald, G.F., J.L. Cove, C.D. Laughlin JR. \& J. McManus

1989 "Mirrors, Portals, and Multiple Realities", Zygon 24, 39-64.

MADHLOOM, T.A.

1969 The Chronology of Neo-Assyrian Art, University of London, London.

MARIN, L.

1993 "Frontiers of Utopia: Past and Present", Critical Inquiry 19, 397-420.

Moretti, F.

1983 “The Dialectic of Fear", Signs Taken For Wonders. Essays in the Sociology of Literary Forms, London, 83-108.

PORADA, E.

1987 "On the Origins of Aquarius", F. Rochberg-Halton, ed., Language, Literature, and History: Philological and Historical Studies Presented to Erica Reiner, New Haven, 279-92.

Postgate, J.N.

1994 "Text and Figure in Ancient Mesopotamia: Match and Mismatch", Renfrew and Zugrow, eds., The Ancient Mind. Aspects of Cognitive Archaeology, Cambridge, 176-84.

READE, J.E.

1979 "Assyrian Architectural Decoration: Techniques and Subject-Matter", Baghdader Mitteilungen 10, 17-49.

REINER, E.

1966 "La magie babylonienne", Le monde du sorcier, Sources Orientales 7, Paris, 69-98.

1987 "Magic Figurines, Amulets, and Talismans", Farkas, Harper and Harrison, eds., Monsters and Demons in the Ancient and Medieval Worlds. Papers Presented in Honor of Edith Porada, Mainz am Rhein.

RitTIG, D.

1977 Assyrisch-babylonische Kleinplastik magischer Bedeutung vom 13.-6. Jh.v.Chr., München.

ROCHBERG-HALTON, F.

1982 "Fate and Divination in Mesopotamia", Archiv für Orientforschung, Beiheft 19, Rencontre Assyriologique Internationale 28, 363-71.

SCHADE, $\mathrm{H}$.

1962 Dämonen und Monstren. Gestaltungen des Bösen in der frühen Kunst des Mittelalters, Regensburg.

SMITH, G.

1876 The Chaldean Account of Genesis, London.

SPERBER, D.

1975 "Pourquoi les animaux parfaits, les hybrides et les monstres sont-ils bons à penser symboliquement?", L'Homme 15, 5-34.

SøHOLM, K.M.

1995 "Frankenstein-myten som ikke vil dø", Cekvina-Nyt 2, 3-7.

TODOROV, T.

1975 The Fantastic. A Structural Approach to a Literary Genre, Ithaca. 


\section{Monstrøsitet som kulturel og religiøs diskurs}

TURNER, T.S.

1977 "Transformation, hierarchy and transcendence: a reformulation of Van Gennep's model of the structure of rites de passage", S.F. Moore and B.G. Meyerhoff, eds., Secular Ritual, Assen, 53-70.

TURNER, V.

1969 "Liminality and Communitas", The Ritual Process: Structure and Anti-Structure, Chicago, 94-130.

1974 Dramas, Fields, and Metaphors. Symbolic Action in Human Society, Ithaca/London.

1977 "Variations on a Theme of Liminality", S.F. Moore and B.G. Meyerhoff, eds., Secular Ritual, Assen, 36-52.

UEBEL, $\mathrm{M}$.

1996 "Unthinking the Monster: Twelfth-Century Responses to Saracen Alterity", J.J. Cohen, ed., Monster Theory. Reading Culture, Minneapolis, 264-91.

WATERHOUSE, R.

1996 "Beowulf as Palimpsest", J.J. Cohen, ed., Monster Theory. Reading Culture, London.

WESTENHOLZ, J.G.

1996 "Symbolic Language in Akkadian Narrative Poetry", M. Vogelzang \& H.L.J. Vanstiphout, eds., Mesopotamian Poetic Language: Sumerian and Akkadian, Cuneiform Monographs, Groningen.

WigGERMANN, F.A.M.

1988 "Exit Talim! Studies in Babylonian Demonology I", Jaarbericht van het VooraziatischEgyptische Genootschap Ex Oriente Lux 27, 90-105.

1992 Mesopotamian Protective Spirits. The Ritual Texts, Groningen.

1993 “Mischwesen A.”, Realleksikon der Assyriologie 8, Berlin, 222-45.

WILCKE, C.

1969 Das Lugalbandaepos, Wiesbaden.

WiLLIAMS, D.

1976 “Aspects du rôle médiateur des monstres", Studies in Religion 6, 267-77.

\section{Summary}

The present contribution attempts to understand and interpret the significance of monstrosity, a well-attested phenomenon in the history of religions. First, monstrosity is interpreted as a mode of cultural discourse pertaining to boundaries and the construction of cultural categories. Its social function is understood along the theories of Girard. The presented view, however, suffers from a lack of adequacy. It neither explains the use of monsters in religious discourses, nor does it indicate why they are often used to bring about transformation and change. In addition to this, it does not offer an explanation for why monsters may be seen as positive and benevolent creatures.

Second, the use of monsters in religious discourses is examined and monstrosity is interpreted in relation to Turner's concept of liminality. The concept, however, is extended to include not only ritual sequences but also spatial and conceptual structures. In religious discourses, monsters can be seen as stigmatized pendlers between this world and 'the other world'. It is claimed that monsters embody access to the transformative powers of transcendence and may thus be used both to ward off evil and to gain access to benevolence.

In the last part of the contribution, these views are illustrated by an analysis of selected narrative and ritual monster traditions from the religions of ancient Mesopotamia. The examples document that monsters are not inherently evil creatures and that it makes sense to understand monsters in relation to boundaries and liminality. In religious discourses, 
monsters are used to focus on the relationship of humans to transcendence: preserving or obtaining blessing and life and warding off curse and death. Monsters are instruments for gaining access to transcendence, they are embodiments of liminality, and they are used to transform the existing order of things. Monsters dissolve differences and thereby thematize the possibility of change. In this manner, the use of monsters contributes to a questioning of fixed classifications and identities.

Laura Feldt

Stud.mag.

Høveltsvangsvej 47

3450 Allerød 